\title{
An Analysis Of A Suitable Study Of Female Students In Information Technology Professions
}

\author{
Ulfi Andayani, Ivan Jaya \\ Department of Information Technology, \\ University of Sumatera Utara, Medan, Indonesia \\ ulfi.andayani@usu.ac.id,ivanjaya@usu.ac.id
}

\begin{abstract}
Everyone has to be successful in life. There is no limitation of gender. Women have many top achievement in education. Computer measure has four clumps of science and it determines the differences of its graduate profession. The Data in University of Sumatera Utara of Information Technology department show that female students have increased for the admission of new students every year. But, there is no filter of the first time they learn about computer and what the exactly study they become based on their skill especially in female student. The results show that not all part of Information Technology Professional can do by female students especially in networking by ethic which the profession called network technician and male student got higher achievements for 5 years lately in information technology major.
\end{abstract}

Keywords: woman gender; female student; clumps of computer science; information technology professional

\section{INTRODUCTION}

There are much more the development of schools and colleges in the field of information technology. Women have played important roles in the history of computing from 18th-century human computers to 21st-century dot-com entrepreneurs. Their experiences have differed from men's in obvious and subtle ways. For women, choosing a career in computing has often meant ignoring cultural messages about appropriate gender roles as well as overt discrimination. They have had to make the most of limited educational and job options and balance the competing demands of work and family.

From 1970-1990 there was growth in women's participation in science and engineering fields. However, women's participation is still substantially less than participation in other professional occupations. Low penetration of women in science and technology professions means that, as we enter the next century, women will have minimal access to lucrative and in-demand occupations. Rectifying this requires that we understand the forces producing gender stratification in the workforce (Martin, 1999).

In 2008 , only $0.4 \%$ of Bachelor's degrees earned by women were awarded to women of color in computing (National Science Foundation, 2011). Previous research has shown policy and practice that promote the success of women of color in the science, technology, engineering, and mathematics (STEM) disciplines also promote the success of all STEM students (American Physical Society, 2007).

According to the characteristics and influence factors of female career planning development and management, the countermeasures are put forward from three aspects what are the national government, organization and individual female. And then it is considered using information and internet technology to help the female to develop and manage their career planning in computer science era (Q. Luo, 2016).

Some departments in University of Sumatera Utara have more male students than female students but in Department Computer Science and Information Technology University of Sumatera Utara shows that it has greater numbers and higher achievements of male students.

In contrast to some of the above study, we propose a survey method to analyze an achievement of female students in Information Technology professional. This method aims to see the significant difference between male and female student ad determine the interlocking filters that channel the vast majority of women away from professional careers in science and technology (National Science Foundation, 2011). 


\section{MATERIALS AND METHODS}

As we know, the clump of computer science in the world is determined by Association for Computing for Computing Machinery (ACM) whereas in Indonesia is Asosiasi Perguruan Tinggi Informatika dan Komputer (APTIKOM). The aim of the ACM is dedicated to advancing computing as a science and professional. The ACM authors are members of an international task group representative of academic institutions, industry, and professional organizations. The task group is to develop a competency model, called IT 2008, for information technology education within two years based on earlier guidelines and other perspectives (J. Impagliazzo et.al, 2016). Whereas the APTIKOM is an association of college of computer science to collaborate between a stake holder and academics, i.e., lecturers or practitioners in college.

This research used survey, statistic, and the data gathered by study results for every active semester for every student which the used data were classified by their groups. The academic data were from information system academic of Department Computer Science and Information Technology in University of Sumatera Utara for 5 years lately. The general researched methodology can be seen in Fig. 1.

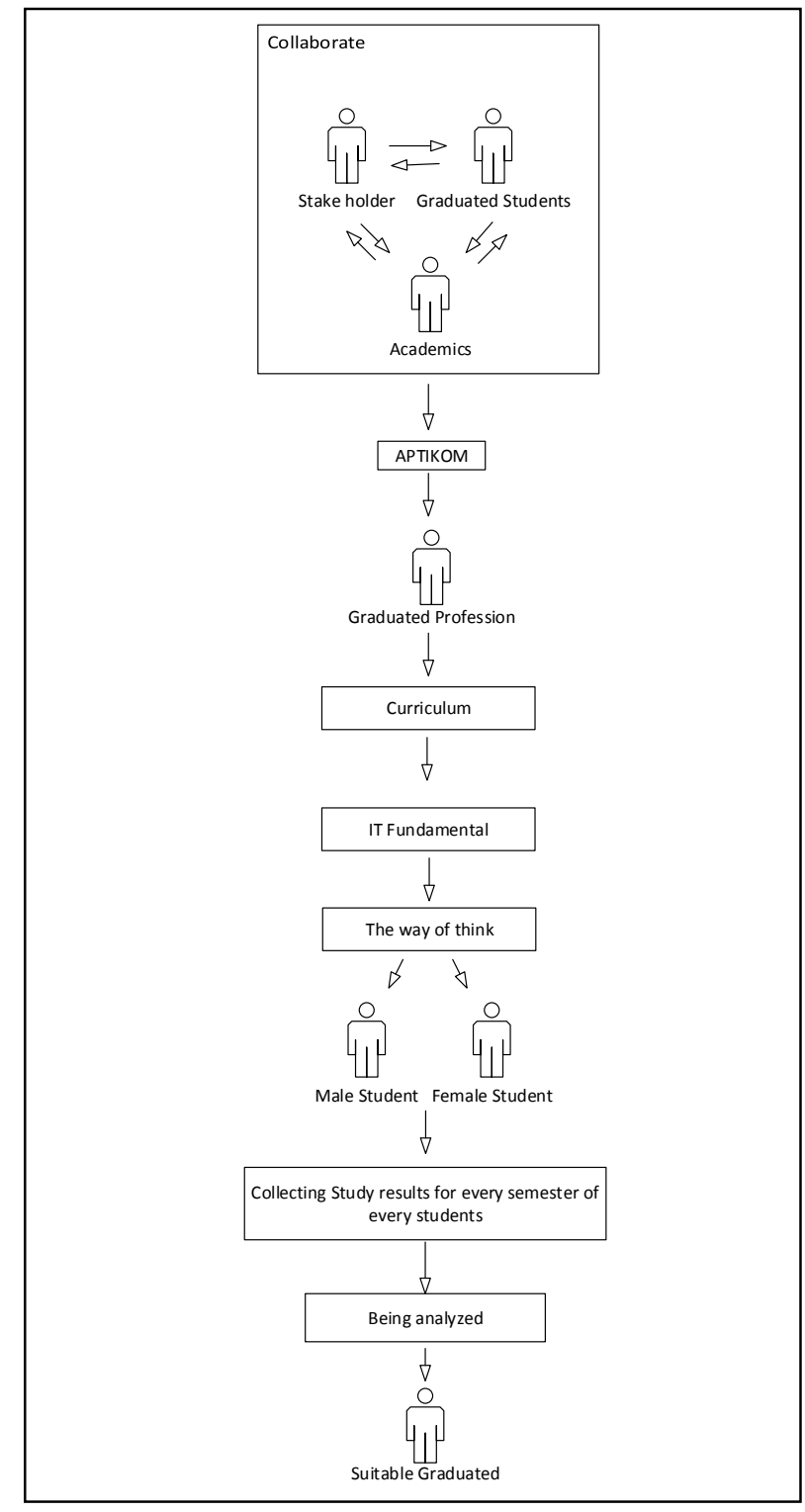

Figure 1. Research Methodology

\section{A. Academic Data collecction}

Data used in this research about 120 students (45 female, 75 male) provides in response to the question are consist of student registration number, student name, years of first registration, major, gender, and grade-point average. The status of student must be active and had graduated. The education level data is bachelor degree because this level show in the age of direction of one's future and sometimes they are confused or do not know what they are want to be.

\section{B. ACM Curricula Data}

In the decades since the 1960s, ACM, along with leading professional and scientific computing 
societies, has endeavored to tailor curriculum recommendations to the rapidly changing landscape of computer technology. As the computing field continues to evolve, and new computing-related disciplines emerge, existing curriculum reports will be updated, and additional reports for new computing disciplines will be drafted.

The overview report computing curricula 2005 provides undergraduate curriculum guidelines for five defined sub-disciplines of computing, i.e., computer science, computer engineering, information systems, information technology, and software engineering. We use 2 curriculum based on computer science and information technology faculty major, i.e., computer science and information technology curriculum. Although, information technology curriculum does not based on ACM but computer science does.

\section{Aptikom Data}

When a major in faculty want to make curriculum, it need a meeting among stake holder, professional and academics. They will decide what actual skill the graduates need to overcome problem by using technology in real life. Aptikom will list a graduate profession who will be a correlation between profession and subjects that should be learned in the class. The subjects will exactly produce skills that are need by the companies. So, subjects had determined in curriculum to produce skills of students. The latest Subjects were describes in ACM Curriculum. Academics will choose the subjects based on what graduated students they want to be created where the latest graduated students were describe in Aptikom. Here, the researcher choose IT 2008 curriculum for information technology major. The general IT Fundamental in IT 2008 ACM Curricula can be seen in Fig. 2 .

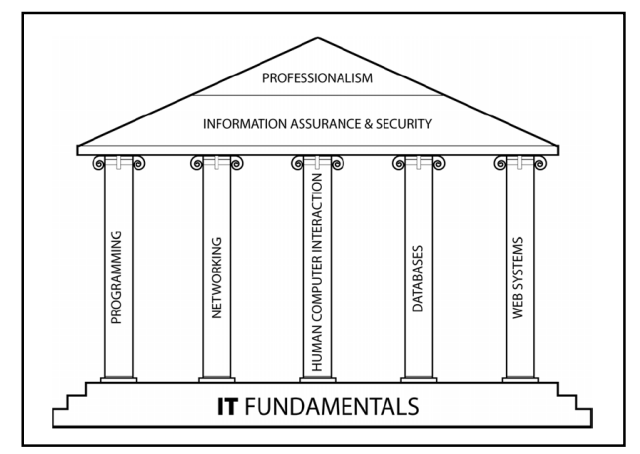

Figure 2. IT Fundamental from ACM
As useful as the body of knowledge is, it is important to complement it with a thoughtful understanding of cross-cutting themes in a curriculum, the "big ideas" of computer science. In designing a curriculum, it is also valuable to identify curriculum-wide objectives, for which the Principles and the Characteristics of Graduates chapters of this volume should prove useful (ACM Delegation, Dec, 2013).

As an academic discipline, Information Technology focuses on preparing graduates who are concerned with issues related to advocating for users and meeting their needs within an organizational and societal context through the selection, creation, application, integration and administration of computing technologies. In academia, it refers to undergraduate degree programs that prepare students to meet the computer technology needs of business, government, healthcare, schools, and other kinds of organizations. in some nations, other names are used for such degree programs. (J. J. E. S. G. G. H. R. K. E. L. E. L. J. M. H. R. Barry M. Lunt, Nov, 2008)

\section{RESULT AND DISCUSSION}

The data were taken from academic information system in the Faculty of Computer Science And Information Technology in University of North Sumatera for lately 5 years.

Table I. Skills in faculty of computer science and information technology, usu, total students for 5 years lately

\begin{tabular}{|l|l|l|l|}
\hline Skill & $\begin{array}{l}\text { Mea } \\
\text { n }\end{array}$ & $\begin{array}{l}\text { Media } \\
\text { n }\end{array}$ & $\begin{array}{l}\text { Std } \\
\text { Dev. }\end{array}$ \\
\hline Public speaking ability & 2.05 & 2 & 1.03 \\
\hline Math ability & 3.67 & 4 & 0.59 \\
\hline Science ability & 3.21 & 4 & 0.77 \\
\hline $\begin{array}{l}\text { Computer/programmi } \\
\text { ng skills }\end{array}$ & 3.02 & 3 & 0.76 \\
\hline $\begin{array}{l}\text { Written } \\
\text { communication }\end{array}$ & 2.53 & 3 & 0.72 \\
\hline Business ability & 3.03 & 3 & 2.3 \\
\hline
\end{tabular}

Based on skills that were categorized by their subjects showed that mean of math ability, science, computer and business ability were really needed to study in this faculty of computer science and information technology. 
Table II. Correlation matrix, importance of skills in Computer Science And Information Technology, USU, $(n=30)$

\begin{tabular}{|l|l|l|l|l|l|}
\hline & Math & $\begin{array}{l}\text { Scien } \\
\text { ce }\end{array}$ & $\begin{array}{l}\text { Comp } \\
\text { uter }\end{array}$ & $\begin{array}{l}\text { Public } \\
\text { speaking }\end{array}$ & $\begin{array}{l}\text { Written } \\
\text { comm. }\end{array}$ \\
\hline Science & $0.89^{*}$ & & & & \\
\hline Computer & $0.59^{*}$ & $0.68^{*}$ & & & \\
\hline $\begin{array}{l}\text { Public } \\
\text { speaking }\end{array}$ & 0.13 & 0.04 & 0.06 & & \\
\hline $\begin{array}{l}\text { Written } \\
\text { comm. }\end{array}$ & 0.06 & 0.13 & 0.68 & $0.23^{*}$ & \\
\hline Business & 0.32 & 0.35 & 0.76 & $0.42^{*}$ & $0.07^{*}$ \\
\hline
\end{tabular}

Based on the correlation matrix above, math and science, science and computer, computer and business had a big correlation in subject of student achievements.

Table III. Ratings of important abilities, by gender, skills in Computer Science And Information Technology, USU, $(n=30)$

\begin{tabular}{|c|c|c|c|c|}
\hline & SKILL & MEAN & MEDIAN & $\begin{array}{l}\text { STD } \\
\text { DEV. }\end{array}$ \\
\hline \multirow{6}{*}{$\sum_{12}^{2}$} & $\begin{array}{l}\text { Public speaking } \\
\text { ability }\end{array}$ & 3.76 & 3 & 1.4 \\
\hline & Math ability & 2.29 & 2 & 0.73 \\
\hline & Science ability & 3.01 & 3.5 & 0.75 \\
\hline & $\begin{array}{l}\text { Computer/prog } \\
\text { ramming skills }\end{array}$ & 2.01 & 2 & 0.21 \\
\hline & $\begin{array}{l}\text { Written } \\
\text { communication }\end{array}$ & 3.06 & 3 & 2.05 \\
\hline & Business ability & 3.01 & 3 & 1.02 \\
\hline \multirow{6}{*}{$P_{1}^{3}$} & $\begin{array}{l}\text { Public speaking } \\
\text { ability }\end{array}$ & 2.14 & 1 & 0.7 \\
\hline & Math ability & 3.92 & 4 & 1.45 \\
\hline & Science ability & 3.78 & 4 & 1.61 \\
\hline & $\begin{array}{l}\text { Computer/prog } \\
\text { ramming skills }\end{array}$ & 3.96 & 4 & 0.89 \\
\hline & \multicolumn{4}{|c|}{ Written communication } \\
\hline & Business ability & 2.15 & 2.5 & 0.74 \\
\hline
\end{tabular}

Based on these finding, male student had ability in science, programming, and math higher than female student. In return, female students had a skill in communication, public speaking and business also.
Table IV. Total graduated students by gender, USU, ( 5 years lately)

\begin{tabular}{|c|c|c|}
\hline $\begin{array}{l}\text { Years of First } \\
\text { Registration }\end{array}$ & M & F \\
\hline 2007 & 26 & 27 \\
\hline 2008 & 37 & 20 \\
\hline 2009 & 60 & 32 \\
\hline 2010 & 37 & 18 \\
\hline 2011 & 20 & 29 \\
\hline 2012 & 0 & 2 \\
\hline 2013 & 0 & 0 \\
\hline 2014 & 0 & 0 \\
\hline 2015 & 0 & 0 \\
\hline 2015 & $\mathbf{0}$ & 0 \\
\hline
\end{tabular}

The total of male students were 180 while female students were 128 which mean that male students more than student male for 5 years lately.

Table V. total graduated students by cumulative index achievement, USU, (5 years lately)

\begin{tabular}{|c|r|r|r|}
\hline $\begin{array}{l}\text { Achievement } \\
\text { Index }\end{array}$ & $<\mathbf{3 . 0}$ & $\mathbf{3} . \mathbf{0}-<\mathbf{3 . 5}$ & $>\mathbf{3 . 5}$ \\
\hline M & 45 & 88 & 141 \\
\hline F & 15 & 24 & 113 \\
\hline
\end{tabular}

Based on the cumulative achievement index by gender, male students had higher achievement for 3 years lately.

\section{CONCLUSION}

Based on the grouping subjects by the correlation of math and science, science and computer, computer and business had a big correlation in subject of student achievements and skills that were categorized by their subjects showed that mean of math ability, science, computer and business ability were really needed to study in this faculty of computer science and information technology. The finding, male student had ability in science, programming, and math higher than female student. In return, female students had a skill in communication, public speaking and business also but the cumulative achievement index by gender, students female had higher achievement for 3 years lately. 


\section{REFERENCES}

D. o. S. R. S. (2011). 2. National Science Foundation, Women, Minorities, and Persons with Disabilities in Science and Engineering. Special Report NSF 11-309, Arlington, VA. Retreived from http://www.nsf.gov/statistics/wmpd/.

J. Impagliazzo, M. Sabin, H. Alrumaih and B. Viola. (2016). An information technology competency model and curriculum. IEEE Global Engineering Education Conference (EDUCON), United States.

M. R. S. D. K. S.-M. J. L. Z. a. F. A. H. K. I. Maton. (2009). Enhancing the number of African Americans who pursue STEM Ph.D.s: Meyerhoff Scholarship Program outcomes, processes, and individual predictors. Journal of Women and
Minorities in Science and Engineering, vol. 15, pp. 5-37.

Q. Luo. (2016). Female Career Planning Development and Management In Computer Science Era. International Symposium on Computer, Consumer and Control (IS3C), Changchun City, China.

S. Martin. (1999). Gender, technology and work: understanding patterns in women's employment in science and technology occupations, in Technology and Society, 1999. Women and Technology: Historical, Societal, and Professional Perspectives. Proceedings. International Symposium on, Warrensburg. 